world: three started in India Hinduism, Buddhism and Sikhism and three began in the Arab countries Judaism, Christianity and Islam. The second largest religion in Britain, and in the Soviet Union, is Islam. In his foreword to this book, Martin Marty points out that if present trends continue, before many decades pass, Muslims will outnumber Jews to become the second largest faith group in the United States. It is true that the Muslim faith has generated a world. In 1950 , every seventh human in world was Muslim and in 1985, every fifth human followed Islam or bore its name.

Islam, like other religions, exerts its hold because it addresses, and in many ways satisfies, the longings and desires of the people for experience, authority and identity. This book shows how extensive is the reach of the Islamic faith into the dimensions of private and public life, and the chapter on medical ethics reveals how Islam pays attention to detail in doctor-patient relationships. I agree with Professor Rahman when he speaks of his book as the first of its kind in the English language. It may surprise the reader to learn how profound, elaborate and intricate are the elements of Islam that have a bearing on health and medicine. The Holy Qur'an, the treatises from various Muslim sects, the stories attributed to the career of the prophet Mohammed, and other elements of tradition are cited in this book in order to relate the Muslims' search for well-being to the allimportant demand that they follow the Will of God - Allah!

Seven compact chapters deal with: An historical introduction to Islam; Well-being and illness in the view of the Islamic world; The religious values of medicine; Prophetic medicine; Islamic medical care; Medical ethics, and the Islamic concepts of birth, abortion, contraception, sexuality and death. The Epilogue is followed by a list of references and name/subject indexes. Each chapter tells a different story and each story is told with a modern scientific analogy, where possible. This book is for a serious reader or a student of theology and medical ethics. NonMuslims, Westernised Muslims and devout Muslims - looking from different angles - will find considerable valuable information on health, medicine and Islam in this book.

Islamic views on medical ethics are put in a nutshell, with didactic statements, in a chapter which has four sections:- Doctor/patient relationships; Human dignity; The family, and Bioethical issues (for example, organ transplantation, anatomical dissection, genetic engineering, test-tube babies and prolongation of life). These matters are discussed in the light of Islamic teachings, with references to the work of eminent Muslim physicians such as Al-Razi, Nizami and Ibne-Sina. An example of the way one issue is handled: Should a doctor charge a fee, and if so, how much? According to the Prophetic Hadith, it is lawful to pay a physician for his medical services. Al-Ruhavi, the work of Ishaq-ibne-Ali, states that a doctor should earn enough to alleviate the necessity of doing other work, to afford marriage and to raise children, (educating them in the art of medicine) and to lead a comfortable family life. It also suggests that the rich should pay the physician generously so that he can look after the medical needs of the poor without charge. If the rich do not do so, physicians would be forced to give up their medical work and follow some other profession, as a result of which rich and poor alike would suffer. This practice was largely followed by mediaeval physicians in Islam in their private clinics, but not in local free hospitals.

I recommend this book to every doctor who has Muslim patients on his or her list and everyone interested in the Islamic aspects of medical ethics. It is a good buy for every medical library, at home or abroad.

BASHIR QURESHI, General Practitioner 32 Legrace Avenue, Hounslow West, Middlesex TW4 7RS

\section{Efficiency and the NHS: A Case for Internal Markets}

\section{Ray Robinson, 40 pages, London, $£ 4.50$, the IEA Health Unit, 1988.}

This most provocative paper by a member of the King's Fund Institute gives an analysis of the proposal to introduce an internal market to the National Health Service (NHS). So far 'the Thatcher Government's strategy has been to retain the NHS's traditional structure while attemping to increase the efficiency with which the taxpayer's money is used'. As another step the Government has been urged (first by Professor Enthoven of Stanford University) to introduce an internal market in the NHS. According to
Enthoven the NHS needs incentives for increased efficiency: 'It relies on dedication and idealism. It offers few possible incentives to do a better job'.

An internal market would 'seek to organise the trade (of buying and selling services between District Health Authorities (DHAs)) on a systematic basis', where 'each DHA would receive a per capita cash allocation similar to its present RAWP allocation'. DHAs would be paid for services to outsiders and they would also control patient referrals to providers (both NHS and private) outside the districts and would pay for them, 'consultants' contracts would be held at district level and family practitioners would have contracts with DHAs'.

The main part of the paper is an assessment of how an internal market would increase efficiency. The author identifies four sources of potential gain. According to advocates of internal markets, competition is a way of reducing inefficient use of resources: $x$-inefficiency. DHAs would compete for patients, their revenue would partly depend upon their success in doing so. The problem with this suggestion is as the author says 'the level of efficiency in any unit depends upon the ability of management to eliminate waste'. As 70 per cent of NHS costs is labour and a large part of that is doctors' and nurses' wages, in order to increase efficiency greatly managers must improve the efficiency of the work of doctors and nurses. 'It is not clear how exactly competition would spur consultants to work more efficiently'. Also 'This (proposal) would represent a considerable restriction of GPs' existing freedom of referral'. Again it is not clear how this would work, but 'many GPs already refer the majority of their patients to local hospitals and so a "limited list" might not constitute such a large change' and 'Enthoven proposes that GPs' contracts should be held by districts'. This sounds threatening, but what is not discussed in the paper is how managers would decide where to place their contracts, and presumably that would be guided by professional advice and indeed practice.

Also 'a crucial feature of a competitive market is that there should be freedom of entry and exit'. So 'new investment would be required in those districts gaining patients while excess capacity existed elsewhere' but 'it is not clear that a government would be willing to build new capacity while there is excess capacity elsewhere'. There would be a similar problem with labour. The proposal would also mean 
considerable 'movement' of nursing, medical and other staff.

Another source of potential gain may be the economies of scale that specialisation within districts could produce. However, 'the scale effects have been discussed without having been extensively identified', but 'the use of spare capacity (in the NHS and private sectors) offers scope for reducing waiting lists'.

The third source of potential gain is reduced input prices. Again as most of the cost is labour, whether there is much potential for reducing the wages of the major costs, both nursing and medical, is questionable. The ancillary workers have already had their wages reduced and 'any policy which transfers income from them to the taxpayers is likely to increase further inequalities in the distribution of income'.

The fourth potential benefit is 'increased consumer choice' . It is argued that an internal market would allow DHAs to offer 'different packages of care'. These could vary in the quality of both clinical and hospital care, but, 'A commitment to equality of treatment makes any deliberate decision to vary quality of care controversial'.

On the other side of the argument there are a number of problems with introducing an internal market. 'It has been suggested that increased efficiency may be obtained at the cost of unequal access'. Competition would produce greater specialisation which would produce greater concentration. Some patients and their families (and staff) would have to travel further. Some of the benefits to the NHS would be gained at a cost to the patients (which as a group are the less privileged). So it is possible that an internal market may save the NHS money but again there is a redistribution of wealth. And it is even possible that society as a whole may well be worse off.

Then there is a more obscure argument that 'greater awareness of income-generating services can lead to undue emphasis being placed on services that generate income, which may distort planning priorities and 'penalise those individuals who are dependent upon less high profile, basic services'.

The author's tentative conclusion is, 'that there is scope for reducing $x$-inefficiency and reaping some benefits from scale economies. But there are also dangers: more unequal access being one of the most important. Furthermore, the practical problems of implementing such a scheme are considerable. ... 'The lack of cost information is a serious impediment to trade.' Clinical budgeting experiments have been going on for over a decade, but progress has been very slow. As well as the economic doubts, the author also foresees political problems. To implement an internal market and make it work would need the support of GPs and hospital doctors, and as the author notes, 'doubts about the practicality of the proposals hinge as much on their political acceptability to various groups within the NHS as on the potential economic gain to be made'. So there is a need to enlist support. The author concludes that 'there is insufficient evidence to warrant adoption of the idea throughout the NHS' and calls for an experiment within a region. I agree.

DAVID ALLEN Senior Lecturer Health Services Management Unit, University of Manchester, Devonshire House, Precinct Centre, Oxford Road, Manchester

\section{Quantitative Risk Assessment}

\author{
Edited by $\mathrm{J} M$ Humber and R F \\ Almeder, 278 pages, Clifton, New \\ Jersey, £29.00, Humana Press, 1987.
}

In line with the work of Doll and Peto indicating that the great majority of cancers may be environmentally induced, the US National Institute of Occupational Safety and Health (NIOSH) is responsible for conducting Quantitative Risk Assessments (QRAs) intended to result in statements such as: 'The probability of the average person contracting cancer as a result of lowdose exposure (20ppm) to ethylene dibromide for eight hours a day over a 20-year worklife is between 0.73 and 0.87 '. The US government requires that such risk assessments be provided, and that the measure of risk be acceptable, before any new drug or chemical is sold to the public at large. At present the burden of proof is on industries to show that the product is not harmful in any appreciable way.

QRA's are very largely based on exposing a large number of small animals to high doses of the material in question over specified periods of time. The presence or absence of cancerous or precancerous tumours, or other such signs, is noted. The results are then extrapolated, on the basis of conjectural mathematical models, from high doses and small animals to low doses and humans.

Such extrapolations are inevitably suspect. It is stated in the introduction to this book that a senior health official noted that 'some corporations are hiring risk assessors under the conditions that the assessments provided be most conducive to the economic interest of the corporation'. In the early days of atomic weapons testing there appeared to be scientific grounds for positing the existence of a threshold dose of radiation below which no harmful effect would occur. This doctrine, now discredited, clearly suited the aims of those powers that were intent on weapons testing, and although in reality it was always at best conjectural, it was propounded at the time as 'scientific fact' by the powers concerned. In the presence of genuine uncertainty selfserving opinions have a special edge.

This book begins with four essays by practitioners in QRA. The first of these gives a most useful detailed discussion of statistical techniques as applied in a particular case - that of ethylene dibromide. The second essay brings out the need to use background scientific information to supplement the statistical analyses without, however, facing up to the difficulties in doing so. The third points to what is perhaps the most serious unknown in the problem the extent of 'public exposure' to a given risk, varying, as it does, over time and over people. The fourth essay discusses a further related problem - the variability of susceptibility. Pointing out that individuals with high levels of a particular enzyme are more susceptible to the carcinogenic effects of benzpyrene than individuals with low levels of the enzyme, it indicates the social and ethical difficulties in using such information in regulatory practice. It concludes: 'The present state of risk assessment does not allow for incorporation of such refinements as enzyme levels, nor many other physiological considerations, and it calls to mind the appraisal of the discipline of history offered by Herodotus, who said "I am obliged to report what I have heard, but I don't have to believe it"'.

The second section of the book consists of five essays by philosophers, together with an extract from the congressional record describing a Bill introduced to the House of Representatives in 1983 on risk assessment research and demonstration. The first two essays attack the notion that science can be regarded as 'value free', suggesting that 